\title{
Continuous amnioinfusion via an epidural catheter following spontaneous membrane rupture: A case report
}

\author{
Spontan membran rüptürü sonrası epidural kateterle yapılan kontinu amnioinfüzyon: \\ Olgu sunumu
}

\author{
Abdulkadir Turgut ${ }^{1}$, Selahattin Katar², Muhammet Erdal Sak ${ }^{1}$, Fethiye Gülden Turgut ${ }^{3}$, Alparslan Şahin ${ }^{4}$, Serdar Başaranoğlul \\ Ahmet Yalınkaya ${ }^{1}$ \\ 'Department of Obstetrics and Gynecology, Dicle University School of Medicine, Diyarbakur, Turkey \\ ${ }^{2}$ Department of Pediatrics, Veni Vidi Hospital, Diyarbakır, Turkey \\ ${ }^{3}$ Department of Ophthalmology, Diyarbakir Training and Research Hospital, Diyarbakir, Turkey \\ ${ }^{4}$ Department of Ophthalmology, Dicle University School of Medicine, Diyarbakır, Turkey
}

\section{Abstract}

\begin{abstract}
Preterm premature rupture of membranes (PPROM) is seen in $3 \%$ of all pregnancies, and is a frequent cause of preterm birth, neonatal mortality and morbidity. The most important complications are maternal and foetal infection, prematurity, umbilical cord compression, hypoxia or asphyxia due to cord prolapse, pulmonary hypoplasia and extremity deformities. The basic approach to PPROM therapy aims to prevent premature birth and the development of foetal distress, and decrease the risk of maternal and foetal infection, and amniotic fluid loss. In compliance with these objectives, alternatives of PPROM therapy demonstrate a wide spectrum, including watchful waiting, amniopatch application, recurrent amnioinfusions and emergency birth. However, repeated amnioinfusions in cases of fluid loss, especially within 6 hours of therapy, provides only minimal benefit. In this case presentation, we attempted to describe a different and cost-effective continuous amnioinfusion technique performed to confer survival benefit for an immature anhydramniotic foetus affected by PPROM at the border of viability.

(J Turkish-German Gynecol Assoc 2013; 14: 238-41)
\end{abstract}

Key words: Amnioinfusion, preterm premature rupture of membranes, amniopatch

Received: 04 January, 2013

Accepted: 21 April, 2013
Özet

Preterm prematür membran rüptürü (PPROM) tüm gebeliklerin \%3'ünde görülür ve preterm doğumun, neonatal ölüm ve morbiditenin en sık nedenidir. En önemli komplikasyonlar maternal ve fetal enfeksiyon, prematürite, umblikal kord basısı, kord prolapsusuna bağlı hipoksi veya asfiksi, pulmoner hipoplazi ve ekstremite deformiteleridir. Tedavisinde temel yaklaşım prematüre doğumun önlenmesi, anne ve fetüs te enfeksiyon riskinin azaltılması, amnion sıvı kaybının azaltılması ve fetal distres gelişiminin önlenmesidir. Bu amaçlar doğrultusunda tedavisi de bekleme tedavisi, amniopatch, tekrarlayan amnioinfusyondan acil doğuma kadar oldukça çeşitlilik göstermektedir. Ancak özellikle de tedavi sonrası 6 saat içinde sıvı kaybının fazla olduğu vakalarda tekrarlayan amnioinfüzyon minimum fayda sağlamaktadır. Bu vaka sunumunda, PPROM nedeniyle anhidramnios olan immatür bir fetusun viabilite sınırını geçmesi için yapılan ve başarılı olan farklı ve ucuz bir kontinu amnıoinfüzyon tekniğini anlatmaya çalıştık. (J Turkish-German Gynecol Assoc 2013; 14: 238-41)

Anahtar kelimeler: Amnioinfüzyon, preterm prematür membran rüptürü, amniopatch

Geliş Tarihi: 04 Ocak 2013

Kabul Tarihi: 21 Nisan 2013

\section{Introduction}

Premature rupture of the foetal membranes (PROM) is defined as the rupture of the amniotic membranes and the resultant leakage of the amniotic fluid at least one hour prior to labour contractions. PROM may be subdivided into term PROM (TPROM, i.e. PROM after 37 weeks of gestation) and preterm PROM (PPROM, i.e. PROM prior to 37 weeks of gestation) (1). The incidences of PROM and PPROM are 19.53\% and $3 \%$, respectively. It is a frequent cause of preterm birth, neonatal mortality and morbidity $(2,3)$. The incidence of peri- natal mortality is $60 \%$, and nearly one-third of these deaths occur in utero. The most important complications are maternal and foetal infection, prematurity, umbilical cord compression, hypoxia or asphyxia due to cord prolapse, pulmonary hypoplasia and extremity deformities (1, 4, 5). The basic approach to PPROM therapy aims to prevent premature birth and the development of foetal distress and to decrease the risk of maternal and foetal infection and amniotic fluid loss. In light of these objectives, PPROM therapy demonstrates a wide spectrum, including watchful waiting, amniopatch application, recurrent amnioinfusions and emergency birth. 
However, repeated amnioinfusions in cases of fluid loss, especially within six hours of therapy, provide only minimal benefit. Major cerebral anomalies, such as cerebral palsy, chronic pulmonary disease, necrotising enterocolitis and blindness, can be seen in infants who survive $(3,6)$.

In this case presentation, we describe a different and cost-effective continuous amnioinfusion technique performed to confer a survival benefit on an immature anhydramniotic foetus with PPROM at the border of viability.

\section{Case Report}

A 37-year-old pregnant woman (gravida 5, para 1, abortus 3) at her $22^{\text {nd }}$ gestational week with antiphospholipid syndrome who had previously given birth to a 27 -week premature healthy and still living infant consulted our clinic with a complaint of 'water breaking' amniotic fluid. On ultrasonographic examination (US) (by GE Voluson 730 Pro 4D ultrasound device), the foetus was at nearly the $22^{\text {nd }}$ gestational week, and the amount of total amniotic fluid according to the amniotic fluid index (AFI) was less than $2 \mathrm{~cm}^{3}$ as viewed from all quadrants. PPROM was diagnosed with a speculum, which showed vaginal pooling of the fluid on the posterior fornix, and by a positive alpha microglobulin-1 protein test (Amnisure; Aren Medical, İstanbul, Turkey) of the vaginal fluid. It is probable that the membranes had ruptured much earlier and that the fluid loss had been misinterpreted by the patient as a weakness of the bladder. The cervical length was $25 \mathrm{~mm}$. The patient's treatment started with prophylactic antibiotics, a regimen of bed rest, daily monitoring of inflammation parameters, such as the white blood cell (WBC) and C-reactive protein (CRP), and the monitoring of vital signs, especially temperature. The CRP and WBC measurements were $<1 \mathrm{mg} / \mathrm{dL}$ and $17,700 / \mathrm{mm}^{3}$, respectively. Prophylactic IV antibiotherapy was initiated with $4 \times 1$ g of ampicillin+sulbactam (Sulbaksit; Tüm Ekip İlaç, İstanbul, Turkey). An amniopatch was performed primarily with the use of platelet suspension. The autologous platelet concentrate (PC) was produced by platelet pheresis using the MCS plus ${ }^{\circledR}$ blood cell separator (Haemonetics Corporation, Braintree, Massachusetts, USA). The patient's platelet precount of $230 \times 10^{3} / \mu \mathrm{L}$ was used for programming the device. After rewarming to $37^{\circ} \mathrm{C}$, the $\mathrm{PC}(30 \mathrm{~mL})$ was administered first, followed by $20 \mathrm{~mL}$ of cryoprecipitate via a 22-gauge needle (Spinocan; Braun, Mensungen, Germany), directed into an available pocket of amniotic fluid. The amnioinfusion and the amniopatch were performed twice. After application of the amniopatch, the amniotic fluid continued to drain actively. While monitoring the patient, uterine contractions started to develop, prompting initiation of $2 \mathrm{~g} \mathrm{MgSO}_{4}$ (Magnezyum Sulfat \%15; Osel, İstanbul, Turkey) IV per hour as a tocolytic agent. Within six hours of each application of the amnioinfusion and the amniopatch, the AFI was less than $2 \mathrm{~cm}$ as observed from all quadrants.

Therefore, application of a different and cheaper technique of continuous amnioinfusion was decided upon. Before the procedure, a detailed and undersigned informed consent was obtained from the patient and the family. Continuous amnioinfu- sion was applied through an epidural catheter (Portex Epidural Minipack System, 18 G, Smiths Medical, USA) (Figure 1). The application procedure was similar to the conventional amniopatch method. Under the guidance of ultrasonograpy, an epidural catheter was inserted transabdominally into a suitable vertical pocket of amniotic fluid. After withdrawal of the needle, the cannula was left in the uterine cavity, and a portion of the cannula over the body surface was fixed to the abdomen with gauze bandage and non-allergic plaster (Figure 2). After the procedure, 150-200 cc of isotonic fluid was instilled per hour into the uterine cavity. The mean total amount of amniotic fluid was estimated as $5 \mathrm{~cm}$ during monitoring. One week later, the CRP values increased to $5.52 \mathrm{mg} /$ $\mathrm{dL}$, which required consultation with a specialist in infectious diseases. No symptoms of chorioamnionitis were detected in the patient. The results of urine and blood culture analysis were not remarkable. Nevertheless, the antibiotherapy was changed, and meropenem therapy ( $3 \times 1 \mathrm{~g}$ IV) (Mopem; Tüm Ekip İlaç, İstanbul, Turkey) was initiated. During follow-up, the CRP values decreased to normal, but the leakage of the amniotic fluid continued. However, owing to continuous amnioinfusion, the AFI did not drop below $5 \mathrm{~cm}$ as detected on US examination. At the $24^{\text {th }}$ week of the pregnancy, $12 \mathrm{mg}$ of betamethasone (Celestone; Schering Plough, İstanbul, Turkey) was injected intramuscularly at 12-hour intervals for foetal lung maturation. The patient complained of vaginal bleeding in the $25^{\text {th }}$ gestational week. A physical examination revealed umbilical cord

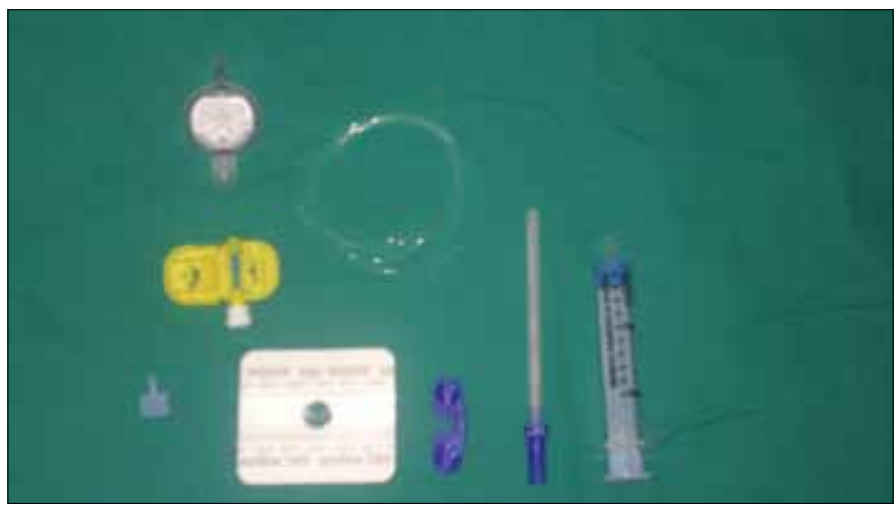

Figure 1. Epidural catheter set used for the patient

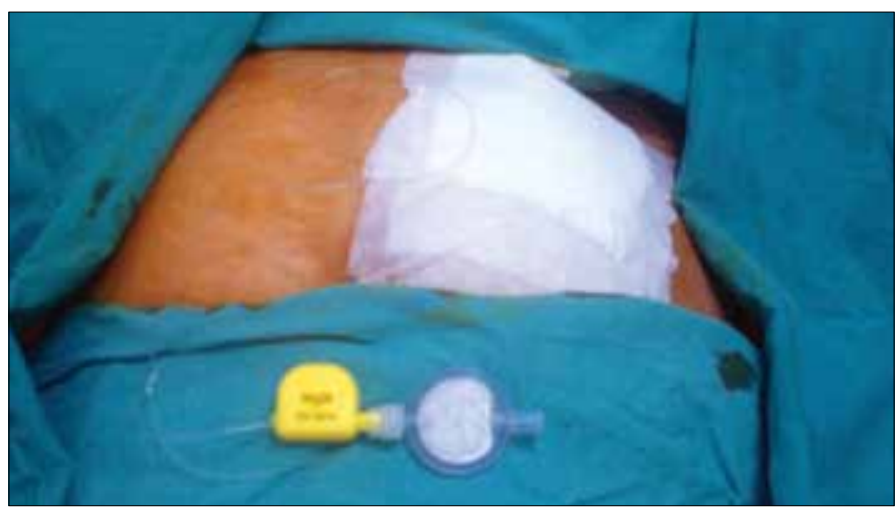

Figure 2. Post-procedural fixation of epidural catheter on the anterior abdominal wall 
prolapse, which necessitated an emergency caesarean section. Postoperatively, the mother was in stable health state, and she was discharged on the $4^{\text {th }}$ postoperative day in full health. At one and five postnatal minutes, the Apgar scores of the infant were 5 and 6 points, respectively. The baby was immediately intubated, and $4 \mathrm{~mL} / \mathrm{kg}$ of surfactant (Survanta; Abbott, North Chicago, USA) was administered through an endotracheal tube, with the diagnosis being respiratory distress. The newborn was connected to a mechanical ventilator. The neonate had a poor general status, weak spontaneous activity, and thin, bright and plethoric skin. The weight was $550 \mathrm{~g}(<3 \%)$, and the height and the head circumference were $27 \mathrm{~cm}(<3 \%)$ and $21 \mathrm{~cm}(<3 \%)$, respectively. The foetal heart rate was rhythmic, and no cardiac murmur was heard. The external appearance of the foetus was of female gender. Her haematocrit was $38 \%$, which necessitated transfusion of an erythrocyte suspension at a rate of $15 \mathrm{~mL} /$ kg. Administration of dopamine (Dopmin amp; Orion, Espoo, Finland) and dobutamine (Dobcard; Vem İlaç, İstanbul Turkey) was initiated due to her deteriorated peripheral circulation. As the mother's membrane rupture was present for three weeks, empirical antibiotherapy was started after drawing blood samples for blood culture. The antibiotherapy was discontinued after the absence of any microbial growth on culture media was reported. Parenteral feeding was started on the first day and minimal enteral feeding on the second day. For the relief of symptomatic patent ductus arteriosus, ibuprofen was used. Respiratory support was provided with a mechanical ventilator for nine days and with a nasal continuous positive airway pressure for four days. An ophthalmologic examination detected Stage 1 retinopathy. On a follow-up visit, no progression of the disease was observed. On the contrary, it had regressed to Stage 0. A hearing test was unremarkable. The infant gained weight, and she was $2070 \mathrm{~g}$ at discharge on the $128^{\text {th }}$ day. The infant is now six-months old and is fed with breast milk and fortified infant formula. On follow-up visits, her development was found to be in accordance with her gestational age.

\section{Discussion}

The current study discussed the use of a relatively cost-effective continuous amnioinfusion technique that can be applied for extended periods in a single session. The method can be used in patients with amniotic fluid loss occurring within less than six hours after undergoing amnioinfusion and an amniopatch who require subsequent repeat applications of these painful procedures and who exhibit foeto-maternal risks.

For the amniopatch application, platelets and cryoprecipitates are usually used because they have been found to be necessary components for a successful and safe therapy for PROM. Sipurzynski et al. (7) did not observe any side effects or complications during autologous platelet pheresis and application of the amniopatch. In cases of PROM occurring after an iatrogenic procedure, such as amniocentesis performed between the $16^{\text {th }}$ and the $24^{\text {th }}$ gestational weeks, the amniopatch is an appropriate procedure in the absence of intra-amniotic infection. An amniopatch was found to be successful in nearly $50 \%$ of such patients (4). In amniopatch application, platelets seem to migrate to the site of the defect and occlude the defective site. Platelet activation and fibrin formation at the site of rupture initiate the healing process (8). However, after amniopatch application, the development of a fibrous band may cause constriction of an extremity or the umbilical cord. In the present case, the failure of the amniopatch application was probably related to a larger membrane defect.

Before 24 weeks of gestational age, PPROM has a predicted perinatal mortality of nearly $90 \%$ and amniotic infection is frequently seen. Perinatal outcomes of an iatrogenic PROM like amniocentesis are relatively worse when compared with spontaneous PROM. Repeated amniopatch or saline amnioinfusion techniques can be applied. However serial applications of this method are quite painful and carry important foeto-maternal risks $(9,10)$.

Tchirikov et al. (11) previously applied a method similar to that reported here. They used an amniotic fluid replacement port. Our system works in a similar way. There were some disadvantages with the system described by Tchirikov et al. (11). The catheter had to be detruncated and reconnected to a metal tube and then to the port capsule. Fluid leakage around the catheter was also detected. Additional disadvantages were important technical problems and the need for anaesthesia (11). Our application technique is independent of gestation weeks. Saline is infused in a method similar to that of Tchirikov et al. (11). The technique did not lead to fluid leakage in the presented case. Moreover, it does not require detailed technical information, and is relatively cost-effective. In addition, it does not necessitate additional procedures, such as skin incision.

Inflammation secondary to microbial invasion of the amniotic cavity is responsible for more than half of cases with preterm birth and PPROM (11). However, in cases with previable PPROM ( $<22-23$ gestational weeks), termination of the pregnancy can be recommended because of poor prognosis secondary to infection and/or pulmonary hypoplasia (3). In the present study, no infection developed, although there was a slight increase in CRP. The infant remained connected to the mechanical ventilator for only nine days and continues to exhibit no pulmonary problems. Continuous intra-amniotic infusion of an isotonic saline solution may be able to protect the patient from the development of amniotic infection syndrome and pulmonary hypoplasia. An isotonic saline solution, which drains from the uterine cavity through the cervical canal, provides continuous irrigation. This might protect the foetus and the mother from ascending infections.

In conclusion, continuous amnioinfusion using an epidural catheter seems to be an appropriate treatment for PPROM in the second trimester of pregnancy. The aim of such treatment is to prevent cord compression secondary to anhydramnios and pulmonary hypoplasia and to enhance the survival potential of the foetus. The risk-benefit ratio and the expectations of the patient should be taken into consideration in the application of the method. Generally, the only wish of the mother is to embrace their baby.

\section{Ethics Committee Approval: N/A.}

Informed Consent: Written informed consent was obtained from patients who participated in this study. 


\section{Peer-review: Externally peer-reviewed.}

Author contributions: Concept - A.T.; Design - A.T., A.Y.; Supervision - A.T.; Resource - S.K., M.E.S.; Materials - S.B.; Data Collection\&/or Processing - A.T., F.G.T.; Analysis\&/or Interpretation - A.T., A.S.; Literature Search - F.G.T., S.B.; Writing - A.T.; Critical Reviews - A.T., A.Y.

Conflict of Interest: No conflict of interest was declared by the authors.

Financial Disclosure: The authors declared that this study received no financial support.

\section{References}

1. Simhan HN, Canavan TP. Preterm premature rupture of membranes: diagnosis, evaluation and management strategies. BCOG 2005; 112: 32-7

2. Liu J, Feng $\mathrm{ZC}, \mathrm{Wu}$ J. The incidence rate of premature rupture of membranes and its influence on fetal-neonatal health: a report from mainland China. J Trop Pediatr 2010; 56: 36-42. [CrossRef]

3. Porat S, Amsalem H, Shah PS, Murphy KE. Transabdominal amnioinfusion for preterm premature rupture of membranes: a systematic review and metaanalysis of randomized and observational studies. Am J Obstet Gynecol 2012; 207: 393.e1-11.

4. Quintero RA. Treatment of previable premature ruptured membranes. Clin Perinatol 2003; 30: 583-9. [CrossRef]

5. Meis PJ, Goldenberg RL, Mercer BM, Iams JD, Moawad AH, Miodovnik M, et al. The preterm prediction study: risk factors for indicated preterm births. Maternal-Fetal Medicine Units Network of the National Institute of Child Health and Human Development. Am J Obstet Gynecol 1998; 178: 562-7. [CrossRef]

6. De Santis M, Scavo M, Noia G, Masini L, Piersigilli F, Romagnoli C, et al. Transabdominal amnioinfusion treatment of severe oligohydramnios in preterm premature rupture of membranes at lessthan 26 gestational weeks. Fetal Diagn Ther 2003; 18: 412-7. [CrossRef]

7. Sipurzynski-Budrass S, Macher S, Haeusler M, Lanzer G. Successful treatment of premature rupture of membranes after genetic amniocentesis by intra-amniotic injection of platelets and cryoprecipitate (amniopatch): a case report. Vox Sanguinis 2006; 91: 88-90. [CrossRef]

8. Quintero RA, Morales WJ, Allen M, Bornick PW, Arroyo J, LeParc G. Treatment of iatrogenic previable premature rupture of membranes with intra-amniotic injection of platelets and cryoprecipitate (amniopatch): Preliminary experience. Am J Obstet Gynecol 1999; 181: 744-9. [CrossRef]

9. Quintero RA, Morales WJ, Kalter CS, Allen M, Mendoza G, Angel $\mathrm{JL}$, et al. Transabdominal intra-amniotic endoscopic assessment of previable premature rupture of membranes. Am J Obstet Gynecol 1998; 179: 71-6. [CrossRef]

10. Borgida AF, Mills AA, Feldman DM, Rodis JF, Egan JFX. Outcome of pregnancies complicated by ruptured membranes after genetic amniocentesis. Am J Obstet Gynecol 2000; 183: 937-9. [CrossRef]

11. Tchirikov M, Steetskamp J, Hohmann M, Koelbl H. Long-term amnioinfusion through a subcutaneously implanted amniotic fluid replacement port system for treatment of PPROM in humans. Eur J Obstet Gynecol Reprod Biol 2010; 152: 30-3. [CrossRef] 